\title{
DEVELOPING LOCAL CURRENCY BOND MARKETS IN ASIA
}

\author{
Cyn-Young Park
}

NO. 495

August 2016
ADB ECONOMICS WORKING PAPER SERIES 
ADB Economics Working Paper Series

\section{Developing Local Currency Bond Markets in Asia}

Cyn-Young Park

No. 495 | August 2016
Cyn-Young Park (cypark@adb.org) is director of Regional Cooperation and Integration Division in the Economic Research and Regional Cooperation Department of the Asian Development Bank.

The author wishes to thank Pilar Dayag, Grendell Vie Magoncia, Ana Kristel Molina, and Mara Claire Tayag for their excellent research support. 
(C) 2016 Asian Development Bank

6 ADB Avenue, Mandaluyong City, 1550 Metro Manila, Philippines

Tel +632632 4444; Fax +6326362444

www.adb.org

Some rights reserved. Published in 2016.

Printed in the Philippines.

ISSN 2313-6537 (Print), 2313-6545 (e-ISSN)

Publication Stock No. WPS168348-2

Cataloging-In-Publication Data

Asian Development Bank.

Developing local currency bond markets in Asia.

Mandaluyong City, Philippines: Asian Development Bank, 2016.

1. Bond market. 2. Financial integration. 3. Local currency bonds. I. Asian Development Bank.

The views expressed in this publication are those of the authors and do not necessarily reflect the views and policies of the Asian Development Bank (ADB) or its Board of Governors or the governments they represent.

ADB does not guarantee the accuracy of the data included in this publication and accepts no responsibility for any consequence of their use. The mention of specific companies or products of manufacturers does not imply that they are endorsed or recommended by ADB in preference to others of a similar nature that are not mentioned.

By making any designation of or reference to a particular territory or geographic area, or by using the term "country" in this document, $A D B$ does not intend to make any judgments as to the legal or other status of any territory or area.

This work is available under the Creative Commons Attribution 3.0 IGO license (CC BY 3.0 IGO)

https://creativecommons.org/licenses/by/3.0/igo/. By using the content of this publication, you agree to be bound by the terms of this license.

This CC license does not apply to non-ADB copyright materials in this publication. If the material is attributed to another source, please contact the copyright owner or publisher of that source for permission to reproduce it. ADB cannot be held liable for any claims that arise as a result of your use of the material.

Attribution - In acknowledging ADB as the source, please be sure to include all of the following information:

Author. Year of publication. Title of the material. (c) Asian Development Bank [and/or Publisher].

URL. Available under a CC BY 3.0 IGO license.

Translations-Any translations you create should carry the following disclaimer:

Originally published by the Asian Development Bank in English under the title [title] (c) [Year of publication] Asian Development Bank. All rights reserved. The quality of this translation and its coherence with the original text is the sole responsibility of the [translator]. The English original of this work is the only official version.

Adaptations-Any adaptations you create should carry the following disclaimer:

This is an adaptation of an original Work (c) Asian Development Bank [Year]. The views expressed here are those of the authors and do not necessarily reflect the views and policies of ADB or its Board of Governors or the governments they represent. ADB does not endorse this work or guarantee the accuracy of the data included in this publication and accepts no responsibility for any consequence of their use.

Please contact pubsmarketing@adb.org if you have questions or comments with respect to content, or if you wish to obtain copyright permission for your intended use that does not fall within these terms, or for permission to use the ADB logo.

Notes:

1. In this publication, "\$” refers to US dollars.

2. Corrigenda to ADB publications may be found at: http://www.adb.org/publications/corrigenda 


\section{CONTENTS}

TABLES AND FIGURES $\quad$ iv

ABSTRACT $v$

$\begin{array}{ll}\text { I. INTRODUCTION } & 1\end{array}$

II. REGIONAL INITIATIVES TO DEVELOP LOCAL CURRENCY BOND MARKETS 2

III. ASIA'S LOCAL CURRENCY BOND MARKETS: THEN AND NOW 3

A. $\quad$ Size and Depth 3

B. $\quad$ Market Maturity Profiles $\quad 7$

C. Issuers and Investors 9

D. Secondary Market Liquidity and Trading 12

IV. DETERMINANTS OF LOCAL BOND MARKET DEVELOPMENT 14

A. Empirical Analysis $\quad 14$

B. Empirical Results $\quad 17$

V. THE CHALLENGES AHEAD 18

A. Size and Liquidity in Secondary Markets $\quad 19$

B. Strengthening the Supportive Market Infrastructure 19

C. Broadening the Investor Base 20

D. Regional Integration 20

$\begin{array}{ll}\text { REFERENCES } & 21\end{array}$ 


\section{TABLES AND FIGURES}

TABLES

$1 \quad$ Bond Market Development Timeline 2

2 Bonds Outstanding in Local Currency Debt Markets, 1995-2015 4

3 Depth of Local Currency Bond Markets, 1995-2015 4

4 Corporate Financing 6

$5 \quad$ Standard \& Poor's Sovereign Credit Ratings 11

$6 \quad$ Local Currency Bond Market Volatility Indicators 14

$7 \quad$ Multivariate Tests for Bond Market Development in Emerging Asia 15

$8 \quad$ Multivariate Tests for Corporate and Long-Term Local Currency Bonds Outstanding 16

\section{FIGURES}

$1 \quad$ Outstanding Local Currency Bonds by Sector, 2015

2 Local Currency Bond Sales in Emerging Asia Excluding India, 1995-2015 7

3 Maturity Profiles of Asian Local Currency Government Bonds, 2000-2015 8

4 Maturity Profiles of Asian Local Currency Corporate Bonds, 2000-2015 8

5 Corporate Bond Issuance by Sector in Global Emerging Markets 10

6 Corporate Bond Issuance by Sector in Emerging Asia 10

$7 \quad$ Credit Default Swap Spreads on Senior 5-year Debt 11

$8 \quad$ Foreign Holdings of Local Currency Government Bonds 12

9 Asian Government Bond Bid-Ask Price Spreads 13

10 Yield Volatility on 10-year Asian Government Bonds 13 


\begin{abstract}
Local currency bond markets in emerging Asian economies have expanded dramatically since governments took steps to end the currency and maturity mismatches that savaged borrowers in the region's financial crisis nearly 20 years ago. Encouraged in part by regional cooperation programs such as the Asian Bond Markets Initiative, the value of local currency government and corporate bond sales has grown fourfold in the past decade, helping to fund much-needed infrastructure development and protect businesses from global financial shocks. However, much more needs to be done to strengthen market infrastructure and institutions, address inconsistent policies and regulations, and enhance corporate governance. This paper presents evidence that better macroeconomic performance and stronger institutions help develop larger local currency bond markets and also create conditions for the growth in local currency sales of corporate debt and bonds with longer maturities. Regional integration can be stepped up to support the key determinants for developing efficient local currency bond markets in emerging Asia.
\end{abstract}

Keywords: bond market, financial integration, local currency bonds

JEL codes: G10, G11, G18 


\section{INTRODUCTION}

The development of local currency bond markets became a policy priority for many Asian economies following the region's financial crisis nearly 2 decades ago. The crisis exposed the damage that using local currency assets to pay maturing foreign-denominated debt can wreak on private sector balance sheets. Relatively stable exchange rates before the 1997-1998 Asian crisis had encouraged firms to take short-term borrowings in foreign currency to fund long-term investments whose returns were tied to the value of their domestic currencies. Since such transactions often were loans from domestic banks, debt default led to massive bank failures during the crisis.

In an effort to better channel regional savings for investment and prevent such risks from mounting again, finance ministers of the Association of Southeast Asian Nations (ASEAN) countries joined with the People's Republic of China (PRC), Japan, and the Republic of Korea in 2003 to introduce the Asian Bond Markets Initiative (ABMI), aiming to develop efficient and liquid local currency bond markets in member countries. National policy efforts coupled with the regional initiatives of the ASEAN+3 focused on developing local debt markets to make bank-dominated financial systems more balanced, to reduce heavy reliance on foreign debts, and to mobilize the region's excess savings more effectively for development finance.

Many emerging Asian economies have seen local currency bond markets grow dramatically in the past 2 decades. Total outstanding local currency bonds in emerging Asia, including India, were about $\$ 10,228$ billion as of December 2015 , up from $\$ 2,568$ billion in 2005 . The main drivers of this growth have been the PRC and the Republic of Korea, but many ASEAN economies have also contributed. The PRC has the largest local currency bond market in emerging Asia, with bonds outstanding of $\$ 6,150$ billion, followed by the Republic of Korea, with $\$ 1,720$ billion in bonds outstanding.

Asian local currency bonds have emerged as a new asset class in part because many traditional assets have lost their shine in the wake of the last global financial crisis. At the height of the crisis, in the last quarter of 2008, Asian local currency bond markets experienced the high volatility and low liquidity associated with large capital outflows. However, investors quickly regained confidence in emerging Asian economies on the back of their relatively strong growth performance, and the monetary easing and fiscal stimulus that occurred around the world. Fueled by favorable global liquidity conditions and regional initiatives, total local currency bond issuance has almost doubled since 2008.

While progress in Asian local currency markets is remarkable, growth has not been universally strong. The growth in local currency bond markets across the region has been largely concentrated in government bonds, leaving room for substantial improvement for emerging Asia's corporate borrowers. Hurdles to developing the market for local currency corporate bonds remain in the shape of market infrastructure and institutions, inconsistent policies and regulations, and-more broadly-in poor corporate governance.

This paper reviews the advances made in developing local currency bond markets in emerging Asia, focusing in the next section on regional initiatives taken to develop local currency bond markets since the 1997-1998 Asian crisis. Section III provides an assessment of various dimensions of local currency bond market development. Section IV empirically investigates economic factors associated with expanding local currency bond markets and discusses their policy implications. Section $V$ suggests key areas for further reforms and concludes that while Asian bond markets are growing at a healthy 
pace, careful and coordinated policies on market development and integration can help resolve significant variations in their efficiency across regions and difficulties on cross-border transactions.

\section{REGIONAL INITIATIVES TO DEVELOP LOCAL CURRENCY BOND MARKETS}

The experience of the Asian crisis of 1997-1998 gave rise to the establishment of regional institutions to safeguard financial stability and build economic and financial resilience. In this context, ASEAN+3 finance ministers introduced several initiatives for regional financial cooperation, including: (i) the Economic Review and Policy Dialogue (ERPD) process as a regional economic surveillance mechanism, (ii) the Chiang Mai Initiative (CMI) as a regional liquidity support facility, and (iii) the Asian Bond Markets Initiative (ABMI) to help develop local currency bond markets (Table 1).

\section{Table 1: Bond Market Development Timeline}

\begin{tabular}{ll}
\hline Year & \multicolumn{1}{c}{ Initiatives } \\
\hline 2003 & Asian Bond Market Initiative (ABMI) is launched under ASEAN+3 to develop a liquid and well- \\
& functioning bond market. \\
& Asian Bond Fund 1 (ABF1) is launched by central banks of the Executives' Meeting of East Asia and \\
the Pacific (EMEAP) countries to invest pooled savings in the region's (sovereign and quasi- \\
sovereign) bond markets. \\
ABMI launches AsianBondsOnline as a one-stop data and information portal for institutional \\
investors, policy makers, and researchers participating in local currency debt markets. \\
Asian Bond Fund 2 (ABF2) starts channeling investment into local currency bonds as a follow-up \\
to ABF1. The primary goal is to reduce market barriers for investors and to improve liquidity in \\
sovereign bond markets. \\
ASEAN+3 ministers sign the New ABMI Road map to set up task forces to address specific issues in \\
local bond market development. \\
ASEAN+3 establishes the Asian Bond Market Forum (ABMF) as a platform to foster \\
standardization of market practices and the harmonization of regulations relating to cross-border \\
bond transactions in the region. \\
The Credit Guarantee and Investment Facility (CGIF) started as a trust fund within the Asian \\
Development Bank to provide guarantees for local currency corporate bonds issued in the region. \\
ASEAN+3 establishes the Cross-Border Settlement Infrastructure Forum (CSIF) to discuss the \\
preparation of a road map and an implementation plan for the improvement of regional cross- \\
border settlement infrastructure. \\
ABMF releases implementation guidelines for the ASEAN+3 Multi-Currency Bond Issuance \\
Framework (AMBIF), which helps facilitate intraregional transactions through standardized bond \\
and note issuance and investment processes. \\
\end{tabular}

Sources: Levinger and Li (2014); ADB (2008, 2012, 2015).

The 2008-2009 global financial crisis further demonstrated the need to strengthen regional financial cooperation. Visible progress has been made toward improving the ERPD, strengthening the $\mathrm{CMI}$ and its multilateralization, and creating the road map for the ABMI.' The ABMI especially aims to "develop efficient and liquid bond markets in Asia to use Asian savings for Asian investments. As the ASEAN+3 Macroeconomic Research Office said in 2013, "the initiative would also contribute to the mitigation of currency and maturity mismatches in financing."

1 The ERPD process has been enhanced and integrated into the multilateralized Chiang Mai Initiative framework (also known as the Chiang Mai Initiative Multilateralization, or CMIM) with its liquidity pool of $\$ 240$ billion. A new surveillance unit, the ASEAN+3 Macroeconomic Research Office (AMRO), was established in Singapore in May 2011 to support the review and dialogue process and the initiative's decision making. 
ASEAN +3 finance ministers signed a new ABMI Roadmap in May 2008 to take the initiative forward, and four task forces were created to: (i) promote the sale of bonds denominated in local currencies (cochaired by the PRC and Thailand), (ii) facilitate demand for local currency-denominated bonds issued (cochaired by Japan and Singapore), (iii) improve the regulatory framework (cochaired by Japan and Malaysia), and (iv) improve related infrastructure for the bond markets with view to encouraging domestic issuance and increasing secondary market liquidity (cochaired by the Republic of Korea and the Philippines)(ADB 2008). The new road map also aims to encourage member economies to take voluntary actions to develop their local currency bond markets and the national efforts are expected to help create a more accessible regional bond market.

ABMI activities have been supported by the introduction of the Credit Guarantee and Investment Facility (CGIF) and the Asian Bond Market Forum (ABMF). The CGIF, a key component of Task Force 1 under ABMI, was established in November 2010 by ASEAN+3 and ADB. The CGIF aims to promote the development of Asian bond markets by providing credit guarantees for local currency bonds issued by investment grade companies in ASEAN +3 countries. ${ }^{2}$ The forum is a working group of experts under Task Force 3 of ABMI who are developing a strategy to harmonize regulations across the ASEAN+3 economies and facilitate cross-border transactions.

Separately, the Asian Bond Funds (ABF) was established by the Executives' Meeting of East Asia Pacific Central Banks (EMEAP) to facilitate investment of the region's international reserves in the region's financial assets. EMEAP launched the first Asian Bond Fund (ABF1) in June 2003, which pooled $\$ 1$ billion of international reserves from the participating eight central banks and invested in the US dollar-denominated sovereign and quasi-sovereign debt issued in these eight economies (the PRC; Hong Kong, China; Indonesia; the Republic of Korea; Malaysia; the Philippines; Singapore; and Thailand). The second Asian Bond Fund (ABF2) in 2005 extended the ABF1 concept with $\$ 2$ billion invested in sovereign and quasi-sovereign issues denominated in local currencies in the same eight markets.

\section{ASIA'S LOCAL CURRENCY BOND MARKETS: THEN AND NOW}

\section{A. Size and Depth}

Local currency bond in emerging Asia reached $\$ 10,228$ billion in value as of December 2015 , after expanding at a 14.8\% compounded annual growth rate between 2005 and 2015 (Table 2). The PRC was the largest local currency bond market in emerging Asia, with outstanding bonds worth \$6,150 billion, followed by the Republic of Korea at $\$ 1,720$ billion. The third-largest bond market in the region was India at $\$ 1,121$ billion.

The PRC local currency bond market now accounts for about $60 \%$ of total bonds outstanding in emerging Asia. Following the PRC, the Republic of Korea has the second-largest bond market in the region, with a $17 \%$ share. The Indian market, the third largest, accounts for $11 \%$. Excluding the PRC, the Republic of Korea, and India, outstanding bonds grew at a $10.6 \%$ compounded annual growth rate between 2005 and 2015 (on a local currency basis).

2 The CGIF has received capital contributions of $\$ 700$ million from ADB, ASEAN, the PRC, Japan, and the Republic of Korea, and operates with a 2.5 leverage ratio that gives it a guarantee capacity up to $\$ 1.75$ billion. 
Table 2: Bonds Outstanding in Local Currency Debt Markets, 1995-2015 (\$ billion)

\begin{tabular}{|c|c|c|c|c|c|c|c|c|c|}
\hline \multirow[b]{2}{*}{ Economy } & \multicolumn{3}{|c|}{ as of $\operatorname{Dec} 2015$} & \multicolumn{3}{|c|}{ as of $\operatorname{Dec} 2005$} & \multicolumn{3}{|c|}{ as of Dec $1995^{a}$} \\
\hline & Government & Corporate & Total & Government & Corporate & Total & Government & Corporate & Total \\
\hline US & $18,901.7$ & $21,019.4$ & $39,921.1$ & $9,801.2$ & $16,629.1$ & $26,430.3$ & $5,499.4$ & $6,102.9$ & $11,602.3$ \\
\hline JPN & $8,274.0$ & 656.0 & $8,930.0$ & $6,301.6$ & 743.7 & $7,045.3$ & $2,763.5$ & $1,093.6$ & $3,857.1$ \\
\hline Emerging & & & & & & & & & \\
\hline Asia & $6,431.5$ & $3,796.5$ & $10,228.0$ & $1,886.4$ & 681.9 & $2,568.3$ & 244.2 & 36.5 & 280.6 \\
\hline PRC & $4,067.0$ & $2,083.0$ & $6,150.0$ & 835.2 & 64.5 & 899.6 & 57.7 & 0.0 & 57.7 \\
\hline HKG & 120.0 & 90.0 & 210.0 & 16.3 & 69.2 & 85.6 & 7.6 & 18.2 & 25.8 \\
\hline IND & 832.5 & 288.2 & $1,120.7$ & 376.7 & 84.7 & 461.4 & 87.1 & 6.8 & 94.0 \\
\hline INO & 109.0 & 18.0 & 127.0 & 48.3 & 5.9 & 54.2 & 0.0 & 2.8 & 2.8 \\
\hline KOR & 700.0 & $1,020.0$ & $1,720.0$ & 392.9 & 360.8 & 753.7 & 67.0 & 0.0 & 67.0 \\
\hline MAL & 142.0 & 118.0 & 260.0 & 61.3 & 45.6 & 107.0 & $\ldots$ & ... & $\ldots$ \\
\hline $\mathrm{PHI}$ & 84.0 & 17.0 & 101.0 & 41.1 & 1.0 & 42.1 & $\ldots$ & $\ldots$ & $\ldots$ \\
\hline SIN & 129.0 & 91.0 & 220.0 & 46.9 & 36.2 & 83.1 & 13.1 & 7.8 & 20.9 \\
\hline THA & 208.0 & 70.0 & 278.0 & 64.9 & 14.1 & 79.0 & 11.5 & 0.9 & 12.4 \\
\hline VIE & 40.0 & 1.3 & 41.3 & 2.7 & 0.0 & 2.7 & $\ldots$ & $\ldots$ & $\ldots$ \\
\hline
\end{tabular}

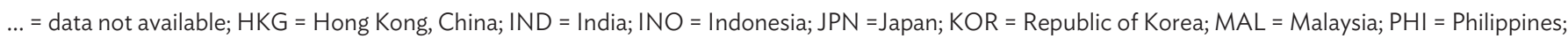
PRC = People's Republic of China; SIN = Singapore; THA = Thailand; US = United States; VIE = Viet Nam.

a As of December 1998 for Japan, and as of December 1997 for the PRC.

Notes: For the United States, government bonds include municipal, Treasury, and Federal agency securities; while corporate includes corporate debt, assetbacked securities, mortgage-related securities, and money market securities. For the rest of the economies, government bonds include the obligations of central government, local governments, and the central bank. Corporates comprise public and private companies, including financial institutions. Financial institutions comprise private and public sector banks, and other financial institutions. Bonds are defined as long-term bonds and notes, treasury bills, commercial paper, and other short-term notes.

Sources: AsianBondsOnline, ADB; Securities Industry and Financial Markets Association for US data.

The local currency bond markets have deepened too. The total outstanding as a share of gross domestic product (GDP) increased to 62.9\% at the end of 2015, from 50.2\% in 2005 (Table 3). The Republic of Korea posted the highest bonds-to-GDP share, at 129.6\%, followed by Malaysia (96.7\%), Singapore (77.7\%), and Thailand (74\%). However, as with their smaller market sizes, local currency corporate bonds have generally shallower market depth than government bonds. The average depth of emerging Asia's corporate bond markets is 23.3\% of GDP. The Republic of Korea has the deepest market at $76.9 \%$ of GDP and it alone has a depth above $50 \%$. The shallowest three corporate bond markets are Indonesia (2.2\%), the Philippines (6.1\%), and Viet Nam (0.7\%).

Table 3: Depth of Local Currency Bond Markets, 1995-2015 (outstanding bonds, \% of GDP)

\begin{tabular}{|c|c|c|c|c|c|c|c|c|c|}
\hline \multirow[b]{2}{*}{ Economy } & \multicolumn{3}{|c|}{ as of Dec 2015} & \multicolumn{3}{|c|}{ as of Dec 2005} & \multicolumn{3}{|c|}{ as of Dec $1995^{a}$} \\
\hline & Government & Corporate & Total & Government & Corporate & Total & Government & Corporate & Total \\
\hline US & 105.3 & 117.1 & 222.4 & 74.9 & 127.0 & 201.9 & 71.8 & 79.6 & 151.4 \\
\hline JPN & 199.4 & 15.8 & 215.2 & 147.3 & 17.4 & 164.6 & 61.3 & 24.2 & 85.5 \\
\hline Asia & 39.6 & 23.3 & 62.9 & 36.9 & 13.3 & 50.2 & 10.6 & 1.6 & 12.2 \\
\hline PRC & 39.0 & 20.0 & 59.0 & 36.3 & 2.8 & 39.1 & 6.0 & 0.0 & 6.0 \\
\hline $\mathrm{HKG}$ & 39.2 & 29.4 & 68.6 & 9.0 & 38.0 & 47.0 & 5.3 & 12.6 & 17.8 \\
\hline
\end{tabular}




\begin{tabular}{|c|c|c|c|c|c|c|c|c|c|}
\hline \multirow[b]{2}{*}{ Economy } & \multicolumn{3}{|c|}{ as of Dec 2015} & \multicolumn{3}{|c|}{ as of Dec 2005} & \multicolumn{3}{|c|}{ as of Dec $1995^{a}$} \\
\hline & Government & Corporate & Total & Government & Corporate & Total & Government & Corporate & Total \\
\hline $\mathrm{INO}$ & 13.0 & 2.2 & 15.2 & 17.1 & 2.1 & 19.2 & 0.0 & 2.4 & 2.4 \\
\hline KOR & 52.7 & 76.9 & 129.6 & 43.2 & 39.6 & 82.8 & 12.6 & 0.0 & 12.6 \\
\hline $\mathrm{PHI}$ & 29.7 & 6.1 & 35.8 & 38.5 & 0.9 & 39.4 & $\ldots$ & $\ldots$ & $\ldots$ \\
\hline SIN & 45.5 & 32.2 & 77.7 & 36.8 & 28.4 & 65.2 & 14.9 & 8.8 & 23.7 \\
\hline THA & 55.4 & 18.6 & 74.0 & 35.0 & 7.6 & 42.6 & 6.9 & 0.5 & 7.4 \\
\hline
\end{tabular}

... = data not available; GDP = gross domestic product; HKG = Hong Kong, China; IND = India; INO = Indonesia; JPN = Japan; KOR = Republic of Korea; MAL = Malaysia; PHI = Philippines; PRC = People's Republic of China; SIN = Singapore; THA = Thailand; US = United States; VIE = Viet Nam.

a As of December 1998 for Japan, and as of December 1997 for the PRC.

Notes: For the United States, government bonds include municipal, Treasury, and Federal agency securities; while corporate includes corporate debt, asset-backed securities, mortgage-related securities, and money market securities. For the rest of the economies, government bonds include the obligations of the central government, local governments, and the central bank. Corporates comprise public and private companies, including financial institutions. Financial institutions comprise private and public sector banks, and other financial institutions. Bonds are defined as long-term bonds and notes, treasury bills, commercial paper, and other short-term notes.

Sources: AsianBondsOnline, ADB; Securities Industry and Financial Markets Association for US data.

Government bonds continue to dominate in most emerging Asian markets except the Republic of Korea (Figure 1). Government bonds in the region account for about $60 \%$ of total local currency bonds outstanding. The Republic of Korea is the only market where more corporate bonds are sold than government bonds.

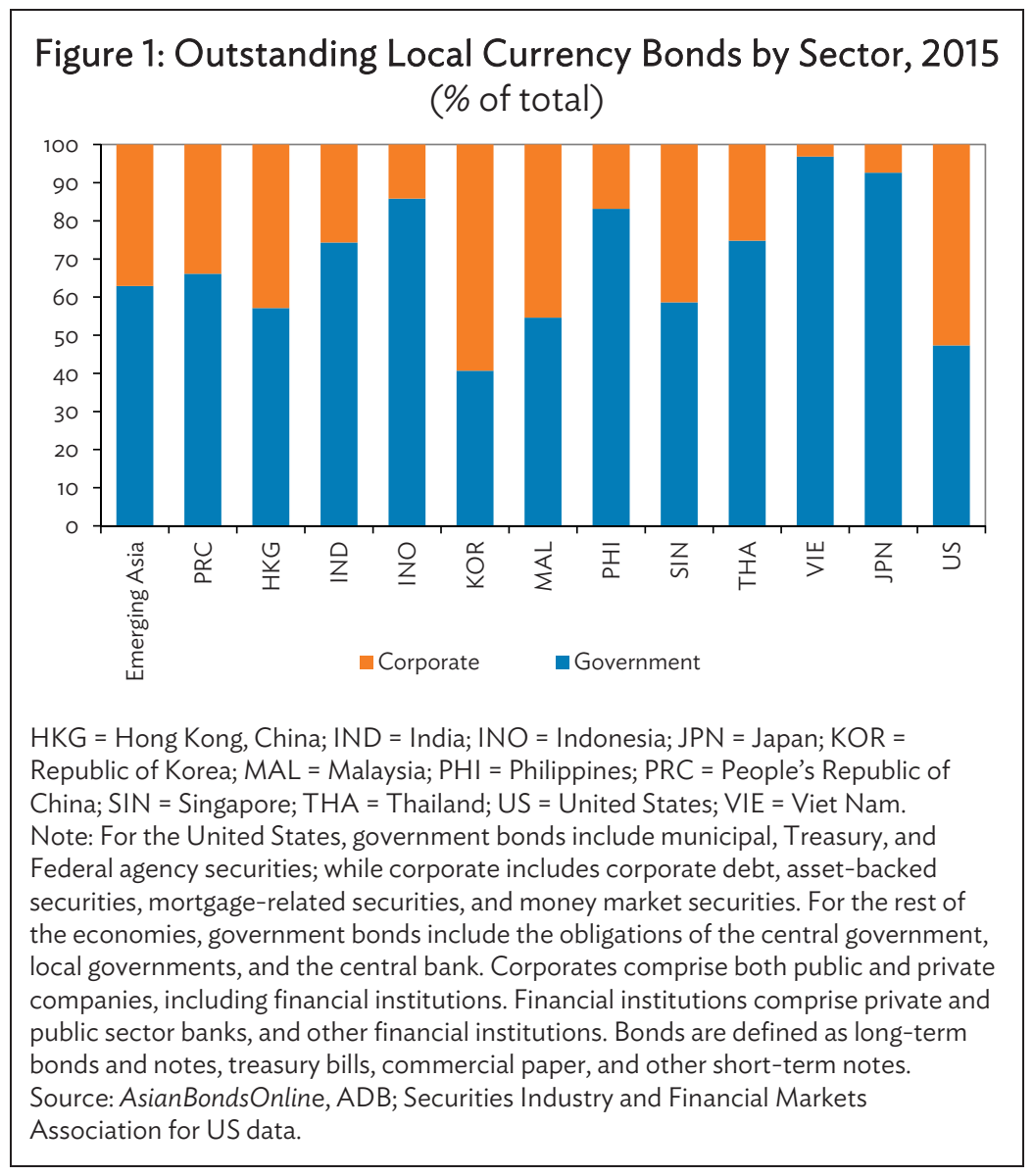


The Asian crisis of 1997-1998 played a catalytic role in creating active local currency bond markets, but it was the global financial crisis of 2008-2009 that fueled growth in the region's local currency bond markets as a new source of funds for both government and corporate issuers. The region's governments turned to the local currency bond markets to finance their fiscal stimulus packages in the postcrisis economic slowdown. Corporate borrowers also resorted to issuing local currency bonds as banks became reluctant to lend while liquidity in global markets had evaporated, particularly after the collapse of Lehman Brothers in 2008.

The corporate bond market plays an increasingly important role in corporate financing (Table 4). While bank lending continues to dominate corporate finance in many emerging Asian economies, equity and bond financing has gained in prominence. Stock market capitalization increased from 77.7\% of emerging Asia's GDP in 1995 to 91.6\% in 2015; and corporate bonds outstanding rose from $1.6 \%$ of GDP to $23.3 \%$. Bank lending still plays the biggest part, at $50 \%$ of corporate financing in 2015 , although it is down a little from $53 \%$ in 2005 . The equity market's share declined to $41 \%$ in 2015 , from $46 \%$; while the corporate bond market's share of corporate financing jumped to $10 \%$ of corporate financing in 2015, from less than 1\% in 2005.

\section{Table 4: Corporate Financing} (\% of GDP)

\begin{tabular}{|c|c|c|c|c|c|c|c|c|c|}
\hline \multirow[b]{2}{*}{ Economies } & \multicolumn{3}{|c|}{2015} & \multicolumn{3}{|c|}{2005} & \multicolumn{3}{|c|}{1995} \\
\hline & $\begin{array}{c}\text { Corporate } \\
\text { Bonds }\end{array}$ & $\begin{array}{c}\text { Stock } \\
\text { Market }\end{array}$ & $\begin{array}{l}\text { Bank } \\
\text { Credit }\end{array}$ & $\begin{array}{c}\text { Corporate } \\
\text { Bonds }\end{array}$ & $\begin{array}{c}\text { Stock } \\
\text { Market }^{\mathrm{a}}\end{array}$ & $\begin{array}{l}\text { Bank } \\
\text { Credit }\end{array}$ & $\begin{array}{c}\text { Corporate } \\
\text { Bonds }\end{array}$ & $\begin{array}{c}\text { Stock } \\
\text { Market }^{c}\end{array}$ & $\begin{array}{l}\text { Bank } \\
\text { Credit }\end{array}$ \\
\hline US & 117.1 & 139.5 & 48.1 & 127.0 & 129.8 & 41.9 & 79.6 & 90.7 & 33.7 \\
\hline JPN & 15.8 & 118.9 & 93.6 & 17.4 & 100.0 & 74.0 & 24.2 & 66.5 & 87.4 \\
\hline Emerging & & & & & & & & & \\
\hline Asia & 23.3 & 91.6 & 116.0 & 13.3 & 66.8 & 84.2 & 1.6 & 77.7 & 78.2 \\
\hline PRC & 20.0 & 71.9 & 131.8 & 2.8 & 17.7 & 105.3 & 0.0 & 70.1 & 94.1 \\
\hline $\mathrm{HKG}$ & 29.4 & 1034.8 & 313.7 & 38.0 & 581.0 & 164.2 & 12.6 & 210.0 & 334.3 \\
\hline IND & 14.6 & 69.5 & 73.8 & 10.3 & 66.3 & 59.0 & 1.8 & 76.1 & 39.7 \\
\hline INO & 2.2 & 40.5 & 32.9 & 2.1 & 26.2 & 22.8 & 2.4 & 27.3 & 20.4 \\
\hline KOR & 76.9 & 88.4 & 83.4 & 39.6 & 79.9 & 67.6 & 0.0 & 32.7 & 35.4 \\
\hline MAL & 43.9 & 122.2 & 111.5 & 31.7 & 121.8 & 93.6 & $\ldots$ & 224.1 & 79.5 \\
\hline $\mathrm{PHI}$ & 6.1 & 79.8 & 37.3 & 0.9 & 38.6 & 26.1 & $\ldots$ & 98.2 & 35.1 \\
\hline SIN & 32.2 & 217.7 & 132.1 & 28.4 & 202.0 & 83.8 & 8.8 & 168.4 & 82.1 \\
\hline THA & 18.6 & 93.4 & 91.4 & 7.6 & 65.4 & 74.6 & 0.5 & 82.9 & 133.2 \\
\hline VIE & 0.7 & 26.1 & 111.6 & 0.0 & 16.4 & 60.2 & $\ldots$ & $\ldots$ & 18.5 \\
\hline
\end{tabular}

... = data not available; HKG = Hong Kong, China; IND = India; INO = Indonesia; JPN = Japan; KOR = Republic of Korea; $M A L=$ Malaysia;

$\mathrm{PHI}=$ Philippines; $\mathrm{PRC}=$ People's Republic of China; SIN = Singapore; THA = Thailand; US = United States; VIE = Viet Nam.

a As of 2008 for Viet Nam.

b As of December 1998 for Japan, and as of December 1997 for the PRC.

c As of 1998 for the PHI and as of 2003 for the PRC and IND.

Notes:

1. On corporate bonds: For the US, government bonds include municipal, Treasury, and Federal agency securities; while corporate includes corporate debt, asset-backed securities, mortgage-related securities, and money market securities. For the rest of the economies, government bonds include obligations of the central government, local governments, and the central bank. Corporates comprise public and private companies, including financial institutions. Financial institutions comprise private and public sector banks, and other financial institutions. Bonds are defined as long-term bonds and notes, treasury bills, commercial paper, and other short-term notes.

2. Bank credit refers to the following-Commercial Bank Credit: Loans and Lease (US); Loans \& Discount: Outstanding: Domestically Licensed Banks (JPN); Financial Institution Loans (PRC); Authorized Institutions: Loans and Advances to Customers (HKG); Commercial Bank: Domestic Credit (IND); Commercial Banks: Loans to Deposit Ratio: Total Credit to Third Party (INO); Loans of Commercial and Specialized Banks (KOR); Commercial Banks: Loans and Advances (MAL); Loans: Universal Commercial Bank (Net of Reverse Repurchase Agreement) (PHI); Domestic Banking Unit: Loans and Advances (SIN); Commercial Bank: Loans (Assets) (THA); Banking Institutions: Claims on Private Sector (VIE).

Sources: AsianBondsOnline, ADB; Securities Industry and Financial Markets Association; World Development Indicators, World Bank; International Monetary Fund; and national sources. 
Local currency bond issuance in emerging Asia excluding India rose substantially to $\$ 1,046$ billion in 2015 from $\$ 346.5$ billion in 2005 (Figure 2). After dropping at the worst of the global financial crisis in 2008, issuances recovered quickly and were driven largely by the PRC and the Republic of Korea. Other regional economies such as Hong Kong, China; Singapore; and Thailand have also shown strong issuance since 2009.

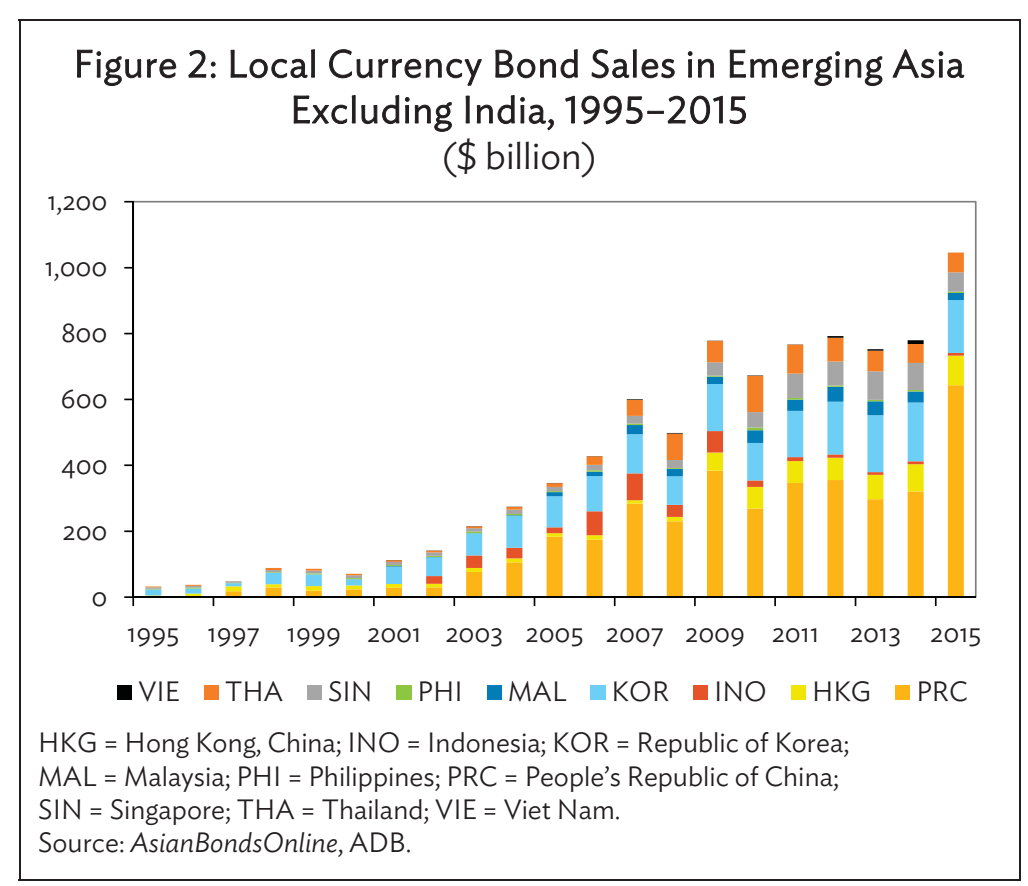

With the exception of the PRC, the lion's share of government bond issuance is from central banks and central governments. Most corporate bond issuance is originated from government-owned corporations, banks, and other nonbank financial institutions. Energy, transport, and other utility companies are the largest of those issuers.

\section{B. Market Maturity Profiles}

Local currency bonds can be issued for the short term (less than 5 years), the medium term (between 5 and 10 years) and the long term (more than 10 years). The term of a bond refers to the length of time from issuance until maturity, when final payment of a debt security (the principal and all remaining interest) falls due. The term structure of a market has implications for the rollover or refinancing risk from an issuer perspective, and for the sensitivity of bond prices to changes in interest rates and broader economic conditions from the perspective of investors. In general, longer-term bonds tend to offer higher yields to compensate investors for greater risk exposures to economic factors.

Figures 3 and 4 show the maturity profiles of local currency government and corporate bonds outstanding. Maturities in the government bond sector have generally got longer, but they are still relatively concentrated at the short end. In Hong Kong, China, 74.6\% of total government bonds outstanding are for terms of less than 5 years, while in Viet Nam the figure is $79.9 \%$. Together with these markets, the PRC, the Republic of Korea, and Malaysia have more than 50\% of their government bonds outstanding with maturities of less than 5 years. Indonesia and the Philippines have structured their government debt since early 2000 s to extend the maturities and their government bonds of more than 10 years are the largest segment of their markets. 
Figure 3: Maturity Profiles of Asian Local Currency Government Bonds, 2000-2015

(\%)

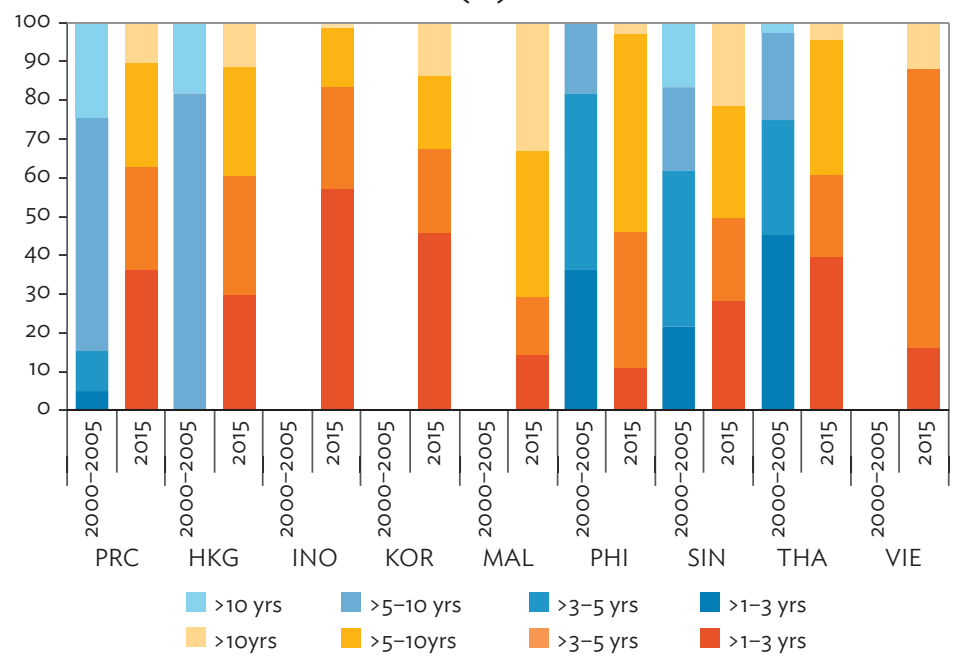

HKG = Hong Kong, China; INO = Indonesia; JPN = Japan; KOR = Republic of Korea; $\mathrm{MAL}=$ Malaysia; $\mathrm{PHI}=$ Philippines PRC = People's Republic of China; $\mathrm{SIN}=$ Singapore; $\mathrm{THA}=$ Thailand VIE = Viet Nam .

Note: 2000-2005 data for THA unavailable.

Source: AsianBondsOnline, ADB.

Figure 4: Maturity Profiles of Asian Local Currency Corporate Bonds, 2000-2015

(\%)

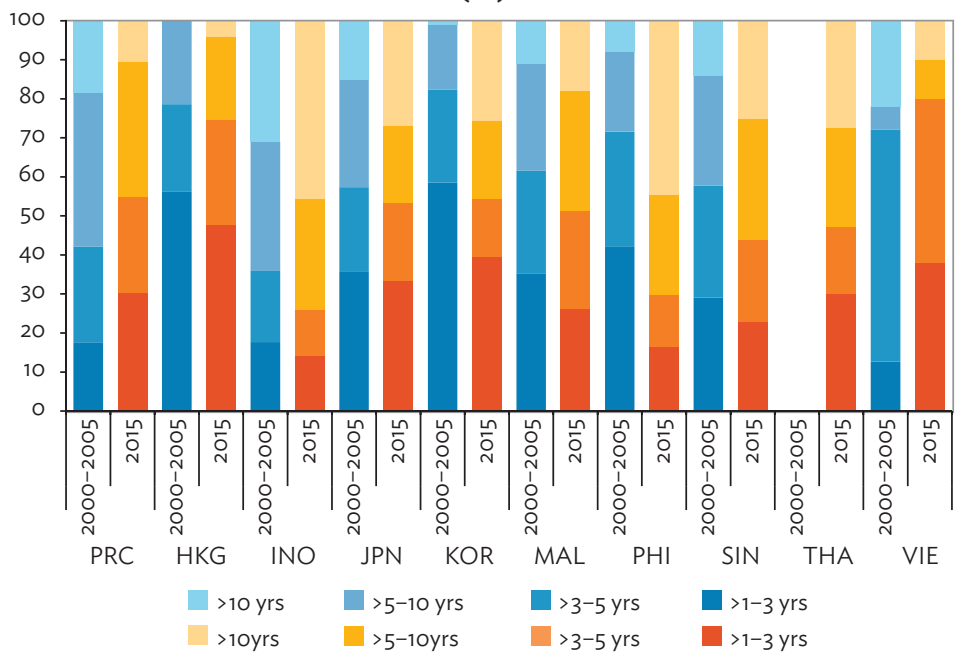

HKG = Hong Kong, China; INO = Indonesia; JPN = Japan; KOR = Republic of Korea; MAL = Malaysia; $\mathrm{PHI}=$ Philippines; $\mathrm{PRC}=$ People's Republic of China; $\mathrm{SIN}=$ Singapore; $\mathrm{THA}=$ Thailand; $\mathrm{VIE}=$ Viet Nam.

Note: 2000-2005 data for INO, KOR, MAL, and VIE unavailable. Source: AsianBonds Online, ADB. 
The maturity profiles of the corporate bond sectors present generally greater concentration on shorter end than those of the government sectors. The Indonesian and Vietnamese corporate sectors have issued proportionately large shares of short-term debts; corporate bonds of less than 5-year maturity account for $83.5 \%$ and $88.1 \%$ of their total corporate bonds outstanding, respectively. The maturity structure of most emerging Asian corporate debt markets has improved, but is still generally skewed toward short-term bonds. With the exception of Malaysia (29.3\%), the Philippines (46.1\%), and Singapore (49.6\%), more than $60 \%$ of corporate bonds in all other emerging Asian economies have maturities of less than 5 years.

Interestingly, corporate bonds sold in Hong Kong, China and Malaysia carry proportionately less short-term and more long-term maturities than their government bonds do. This may be related to many of the corporate issuers in the two economies being in the property development, energy, and infrastructure sectors, which require longer-term financing.

Extending the maturity profile of corporate bonds has been among the major long-term goals in many emerging Asian markets. Over the past decade or so, the medium- to long-term issuance of emerging Asian corporate bonds has increased. This trend continued with the onset of the global financial crisis and the subsequent low interest rate environment contributing to the extension of the maturity profile. A large amount of emerging Asian corporate bonds are due to mature in the next few years.

\section{Issuers and Investors}

A diverse and good-quality issuer base is an essential element of well-developed corporate bond markets. A sizable pool of quality companies is critical for expanding the market size. Major infrastructure companies and financial institutions are often the largest issuers in the early stage of bond market development, but the challenge is to increase the pool of quality issuers by encouraging successful companies in a variety of sectors to tap the bond market. This activity will support private sector growth and better protect the corporate sector from various economic shocks.

Emerging markets have seen growth in both finance sector and nonfinance sector issuances over the past decade, even despite the effect of the crisis in 2008 (Tendulkar and Hancock 2014). In 2000 , corporate bond issuances by the finance sector accounted for just $20 \%$ of total emerging market corporate sector issuances, increasing to 43\% in 2007 (Figure 5). Between 2007 and 2013, finance sector issuance more than doubled, reaching $\$ 241$ billion in 2013 . However, nonfinance sector issuances grew by more than four times, reaching $\$ 692$ billion in 2013. As a result, the share of finance sector bond sales declined to $23 \%$ in 2013. In emerging Asia, corporate bond issuances are also concentrated in the nonfinance sector, mostly the construction, mining, and utilities sectors (Figure 6). Financial services companies issued one-third of the corporate bonds sold in 2009-2013.

The risk-return profile of both government and corporate issuers in emerging Asia is also an important factor when promoting participation in local currency bond markets. Credit ratings represent the credit worthiness of the borrower, with a poor rating indicating high probability of default. Emerging Asian issuers, with their credit ratings steadily improving, offer relatively stable ratings and attractive yields compared to counterparts in other developing regions (Table 5). 
Figure 5: Corporate Bond Issuance by Sector in Global Emerging Markets

(\% of total)

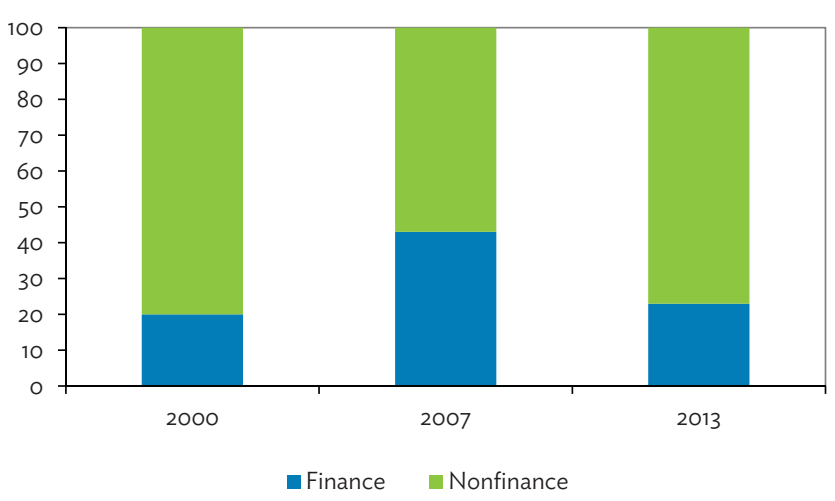

Source: Tendulkar and Hancock (2014).

Figure 6: Corporate Bond Issuance by Sector in Emerging Asia

(\% of total, 2013)

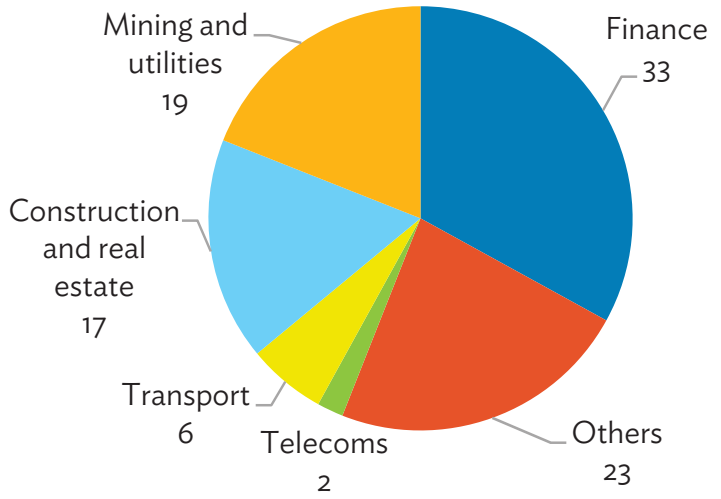

Source: Levinger and Li (2014) 
Table 5: Standard \& Poor's Sovereign Credit Ratings (local currency, long term)

\begin{tabular}{lcc}
\hline Economy & as of Dec 2015 & as of Dec 2000 \\
\hline Japan & $\mathrm{A}+\mathrm{u}$ & $\mathrm{AAA}$ \\
United States & $\mathrm{AA}+\mathrm{u}$ & $\mathrm{AAA}$ \\
Emerging Asia & & \\
People's Republic of China & $\mathrm{AA}-$ & $\mathrm{BBB}$ \\
Hong Kong, China & $\mathrm{AAA}$ & $\mathrm{A}+$ \\
India & $\mathrm{BBB}-\mathrm{u}$ & $\mathrm{BBB}$ \\
Indonesia & $\mathrm{BB}+$ & $\mathrm{B}$ \\
Republic of Korea & $\mathrm{AA}-$ & $\mathrm{A}$ \\
Malaysia & $\mathrm{A}$ & $\mathrm{A}$ \\
Philippines & $\mathrm{BBB}$ & $\mathrm{BBB}+$ \\
Singapore & $\mathrm{AAAu}$ & $\mathrm{AAA}$ \\
Thailand & $\mathrm{A}-$ & $\mathrm{A}-$ \\
Viet Nam & $\mathrm{BB}-$ & $\mathrm{BB}$ \\
\hline
\end{tabular}

Note: For Viet Nam, the earliest rating is as of December 2002. A bond is considered investment grade if its credit rating is BBB- or higher.

Source: Bloomberg, L.P.

Similarly, spreads on credit default swap (CDS) for emerging Asian issuers have narrowed over time (Figure 7). The CDS spreads indicate market sentiment about the riskiness of bond issues. The buyer (bondholder) pays a premium to the seller of the swap agreement for protection in the event of default. The premium, which is the CDS spread, is quoted in basis points per year of the contract's notional amount and the payment is made quarterly. Higher CDS spreads represent higher default risks. The relatively stable and narrow CDS spreads for emerging Asian bond issuers since the end of the global financial crisis suggest favorable market sentiment for their risk conditions.

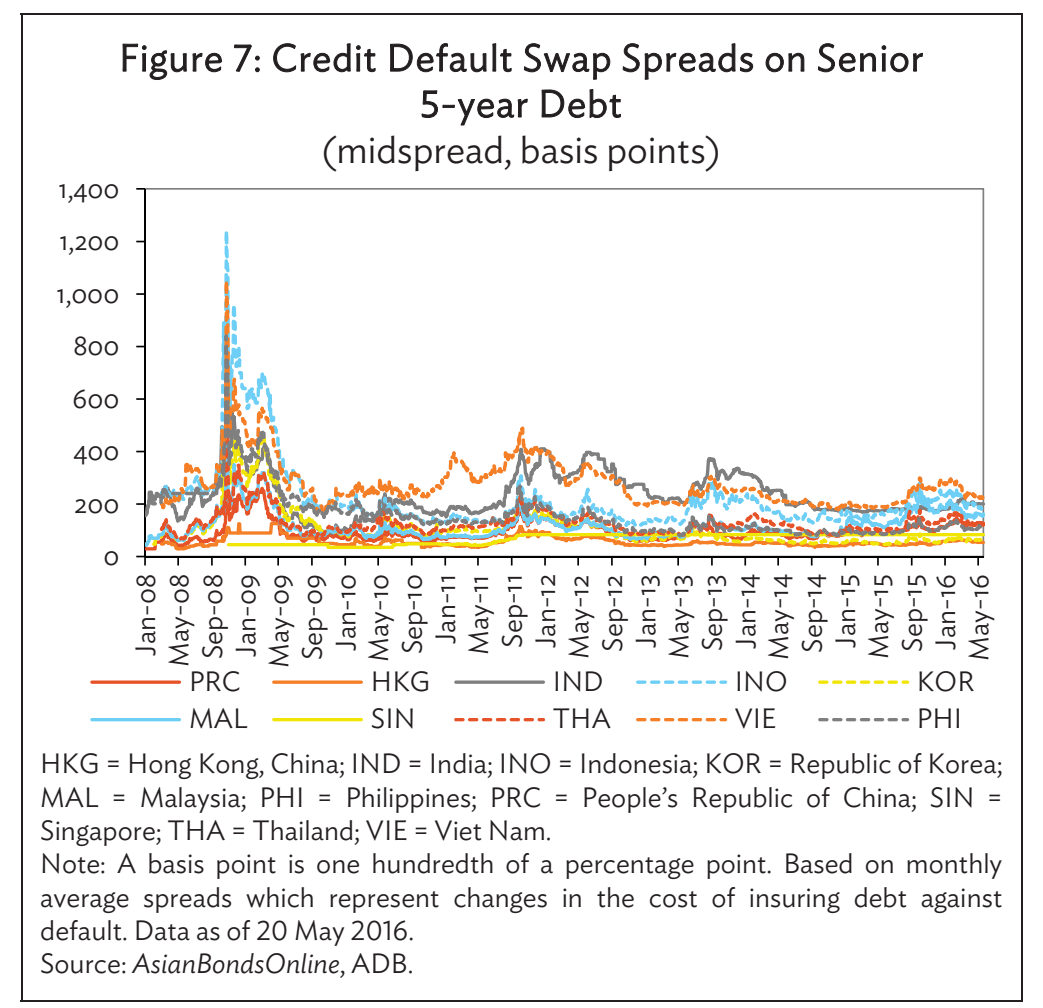


The investor base for emerging Asian local currency bonds has broadened over time. Before the global financial crisis, most government bonds were bought by domestic banks. The growth of local institutional investors, such as pension funds and insurance companies, contributed significantly to the diversity of the investor base. The share of holdings in contractual savings and by other investors (including foreign investors) combined had increased to $65.9 \%$ of total government bonds in Indonesia, $63.7 \%$ in the Republic of Korea, $68.5 \%$ in Malaysia, and $81.0 \%$ in Thailand at the end of 2015. That compared to figures for the respective countries of $63.4 \%, 51.5 \%, 64.9 \%$, and $72.7 \% 5$ years earlier.

Emerging Asian local currency bonds have attracted foreign investors for their relatively good risk-return profiles. Emerging Asian bonds offer attractive yields on the back of the region's robust economic performance following the global financial crisis and gains from ongoing and anticipated currency appreciation. The share of foreign holdings in government bonds has now reached nearly 40\% in Indonesia, more than 30\% in Malaysia, about 14\% in Thailand, and over 10\% in the Republic of Korea (Figure 8).

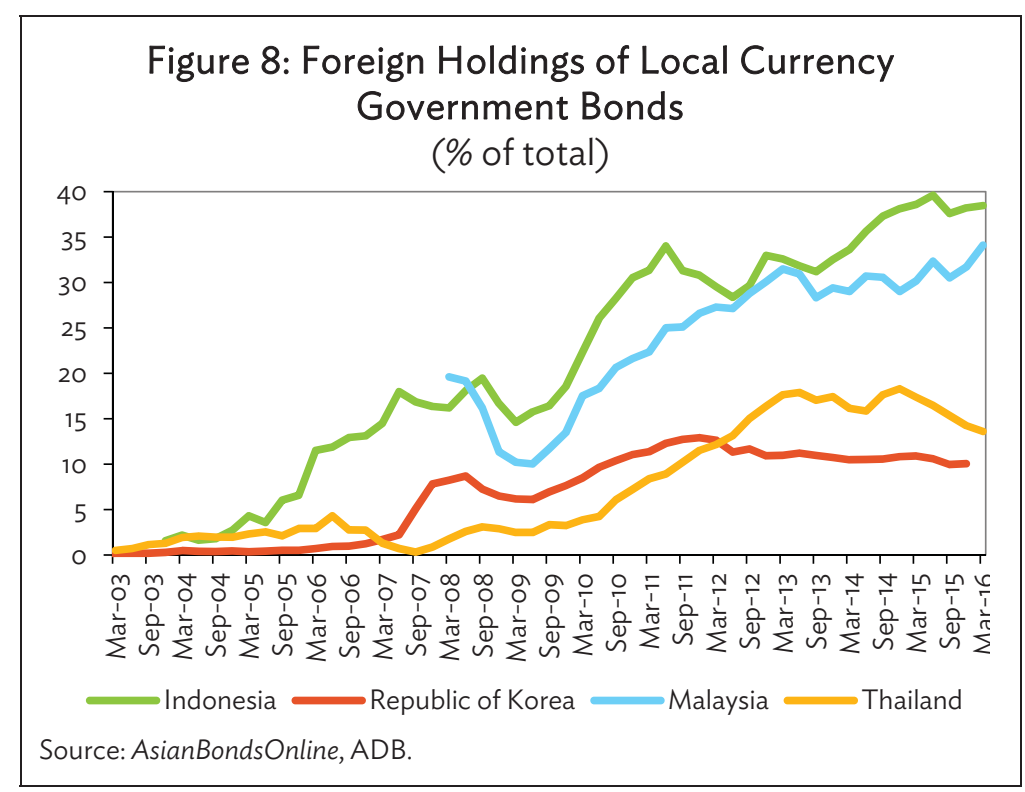

Emerging Asian local currency bond markets have attracted growing interest from emerging market bond funds and global institutional investors like pension and insurance agencies. As foreign investors become increasingly more comfortable with the credit profiles of emerging Asian issuers, global bond flows will likely channel more global savings into the region's local currency bond markets.

\section{Secondary Market Liquidity and Trading}

The growth in the size of local currency bond markets has not translated automatically to a significant improvement in market liquidity. Although secondary market liquidity and trading have been improving in several emerging Asian markets, liquidity varies significantly across the region's local currency bond markets, depending on their overall size, turnover, issuance, and investor bases.

Liquidity is a multidimensional concept and can be measured in terms of market tightness, depth and resilience (Bank of International Settlements 1999). Tightness, often measured by the bid-ask spreads, refers to "how far transaction prices (bid or ask prices) diverge from the mid-market price." Depth, shown 
as the average turnover ratio or bond yield volatility, refers to "either the volume of trades possible without affecting prevailing market prices, or the amount of orders on the order books of market-makers at a given time." Resilience can be defined as either "the speed with which price fluctuations resulting from trades are dissipated, or the speed with which imbalances of order flows are adjusted."

However, data on secondary market liquidity and trading is scarce. For example, bid-ask spreads for particular corporate bonds are not readily available or publicly accessible. Similarly, data on turnover ratios and dealer inventories of corporate bonds is very limited. Where data is available in emerging Asian markets, liquidity appears to be improving. Government bond markets are also more liquid than corporate bond markets.

Emerging Asian government bond market liquidity can be characterized as moderately improving because their bid-ask spreads have narrowed and yield volatility has declined (Figures 9 and 10). Liquidity in the corporate bond markets is relatively poor, with turnover ratios being much lower than for government bonds and even having deteriorated since 2005 (Table 6).

Figure 9: Asian Government Bond Bid-Ask Price Spreads (average over period, basis points)

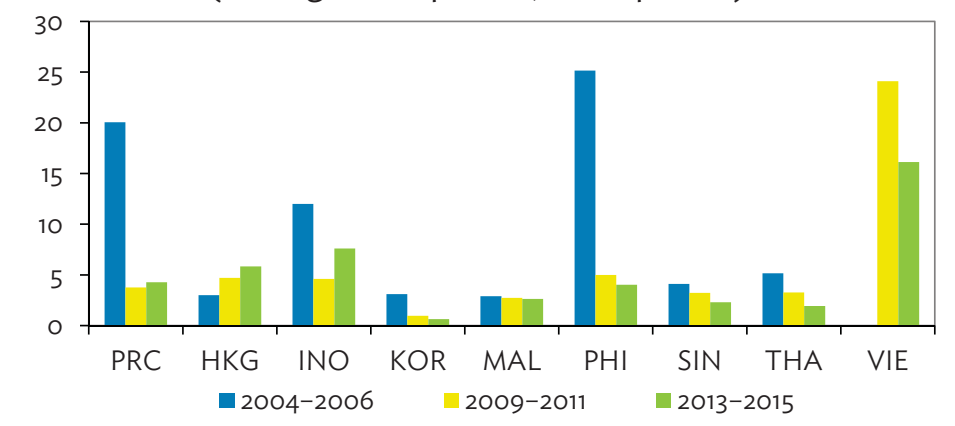

HKG = Hong Kong, China; INO = Indonesia; KOR = Republic of Korea; MAL = Malaysia; $\mathrm{PHI}=$ Philippines; $\mathrm{PRC}=$ People's Republic of China; $\mathrm{SIN}=$ Singapore $; \mathrm{THA}=$ Thailand; $\mathrm{VIE}=$ Viet Nam.

Source: AsianBondsOnline, ADB.

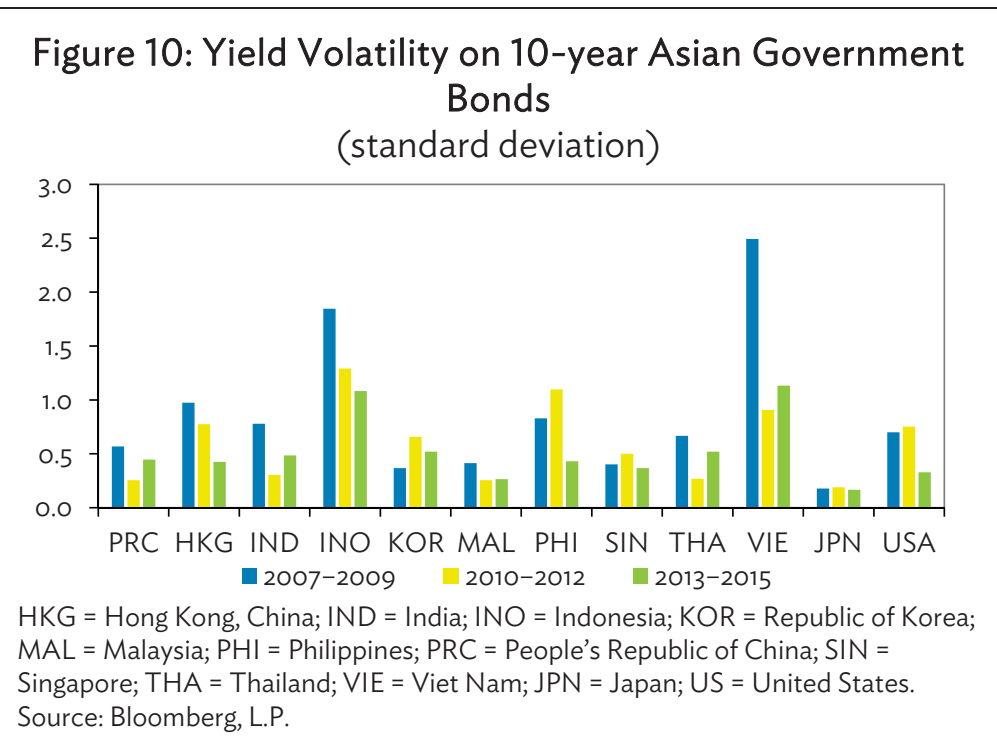


Table 6: Local Currency Bond Market Volatility Indicators

\begin{tabular}{|c|c|c|c|c|c|c|c|c|}
\hline \multirow[b]{3}{*}{ Economy } & \multicolumn{4}{|c|}{ Trade Volume ( $\$$ billion) } & \multicolumn{4}{|c|}{ Turnover Ratio } \\
\hline & \multicolumn{2}{|c|}{2015} & \multicolumn{2}{|c|}{2005} & \multicolumn{2}{|c|}{2015} & \multicolumn{2}{|c|}{2005} \\
\hline & Government & Corporate & Government & Corporate & Government & Corporate & Government & Corporate \\
\hline PRC & $2,476.69$ & 447.12 & 214.19 & 40.11 & 0.63 & 0.29 & 0.27 & 0.73 \\
\hline HKG & 71.14 & 13.75 & 246.31 & 2.29 & 0.61 & 0.16 & 15.15 & 0.03 \\
\hline INO & 53.72 & 2.96 & 6.21 & 0.42 & 0.52 & 0.16 & 0.15 & 0.07 \\
\hline JPN & $10,395.57$ & 36.98 & $7,402.82$ & 130.00 & 1.24 & 0.06 & 1.19 & 0.18 \\
\hline KOR & 413.05 & 97.80 & 270.02 & 57.14 & 0.59 & 0.10 & 0.69 & 0.16 \\
\hline MAL & 38.38 & 5.60 & 19.51 & 7.42 & 0.27 & 0.05 & 0.32 & 0.17 \\
\hline $\mathrm{PHI}$ & 39.07 & $\ldots$ & 12.19 & & 0.49 & & 0.30 & \\
\hline SIN & 34.61 & $\ldots$ & 29.84 & $\ldots$ & 0.47 & & 0.62 & \\
\hline THA & 126.50 & 5.47 & 22.10 & 0.56 & 0.62 & 0.08 & 0.35 & 0.04 \\
\hline
\end{tabular}

... = data not available; HKG = Hong Kong, China; INO = Indonesia; JPN = Japan; KOR = Republic of Korea; MAL = Malaysia; PHI = Philippines;

PRC = People's Republic of China; SIN = Singapore; THA = Thailand.

Source: AsianBondsOnline, ADB. https://asianbondsonline.adb.org/regional/data.php

\section{DETERMINANTS OF LOCAL BOND MARKET DEVELOPMENT}

\section{A. Empirical Analysis}

Empirical work to explore which economic variables help develop local currency bond markets in Asia is limited due to the relatively short history of sales of such debt. Bae (2012) investigated various determinants including macroeconomic, institutional, and capital controls for markets in 43 countries and suggested that the degree of economic development as measured by GDP per capita is the most important factor. Bae (2012) also found that fiscal balance, interest rate, domestic credit provided by banks, and the existence of a well-developed government bond market matter for the development of corporate bond markets. Burger and Warnock (2006) analyzed economic factors associated with local currency bond development using comprehensive data from private and public issuances from 49 countries, placed both at home and abroad. Their main findings suggested that policies and laws matter: stable inflation rates and strong creditor rights lead to more developed local currency bond markets and less reliance on foreign currency-denominated bonds.

This section offers empirical analysis on economic factors associated with local currency bond market development in emerging Asia. Tables 7 and 8 report regression results for the determinants. Table 7 shows the effects of economic factors on (i) the size of local currency bond market measured by the ratio of the local currency bonds outstanding to GDP and (ii) the share of local currency bonds in emerging Asian economies' debt markets combined (which comprise bonds denominated in local and foreign currencies).

To investigate which economic factors matter for corporate and long-term bond market developments more specifically, separate analyses were undertaken for those segments of the local currency bond markets (Table 8). In both analyses, the influence of inflation, rule of law, the fiscal balance (in percent of GDP), and economic size (as measured by the log of GDP) was examined. 
Other control variables that may affect local currency bond market development, such as bank lending, sovereign credit rating, and exchange rate volatility were included.

In both tables, even-numbered columns present results from full regressions, including the control variables.

Table 7: Multivariate Tests for Bond Market Development in Emerging Asia

\begin{tabular}{|c|c|c|c|c|}
\hline & \multicolumn{2}{|c|}{$\begin{array}{c}\text { LCY Bonds Outstanding } \\
\% \text { of GDP }\end{array}$} & \multicolumn{2}{|c|}{$\begin{array}{c}\text { LCY Bonds } \\
\% \text { of total bonds }\end{array}$} \\
\hline & (1) & (2) & (3) & (4) \\
\hline Constant & $\begin{array}{l}-32.521^{* * *} \\
(5.731)\end{array}$ & $\begin{array}{l}-43.865^{* * *} \\
(7.602)\end{array}$ & $\begin{array}{l}60.238^{* * *} \\
(3.752)\end{array}$ & $\begin{array}{l}39.929^{* * *} \\
(4.012)\end{array}$ \\
\hline Inflation & $\begin{array}{l}-0.483^{* * *} \\
(0.15)\end{array}$ & $\begin{array}{l}-0.864^{* * *} \\
(0.274)\end{array}$ & $\begin{array}{l}-0.004 \\
(0.153)\end{array}$ & $\begin{array}{r}0.123 \\
(0.151)\end{array}$ \\
\hline Fiscal balance & $\begin{array}{l}-0.013 \\
(0.193)\end{array}$ & $\begin{array}{r}0.044 \\
(0.196)\end{array}$ & $\begin{array}{r}0.072 \\
(0.122)\end{array}$ & $\begin{array}{r}-0.145 \\
(0.108)\end{array}$ \\
\hline Rule of law & $\begin{array}{l}1.017^{* * *} \\
(0.062)\end{array}$ & $\begin{array}{l}0.810^{* * *} \\
(0.093)\end{array}$ & $\begin{array}{r}-0.039 \\
(0.039)\end{array}$ & $\begin{array}{l}-0.476^{* * *} \\
(0.05)\end{array}$ \\
\hline $\ln (G D P)$ & $\begin{array}{l}4.709^{* * *} \\
(0.777)\end{array}$ & $\begin{array}{l}3.583^{* * *} \\
(0.938)\end{array}$ & $\begin{array}{l}4.890^{* * *} \\
(0.487)\end{array}$ & $\begin{array}{c}0.889^{*} \\
(0.507)\end{array}$ \\
\hline In (Bank lending) & & $\begin{array}{l}1.135^{* *} \\
(0.455)\end{array}$ & & $\begin{array}{l}2.523^{* * *} \\
(0.238)\end{array}$ \\
\hline Sovereign credit rating & & $\begin{array}{l}1.753^{* * *} \\
(0.518)\end{array}$ & & $\begin{array}{l}3.899^{* * *} \\
(0.293)\end{array}$ \\
\hline Forex volatility & & $\begin{array}{r}1.314^{*} \\
(0.645) \\
\end{array}$ & & $\begin{array}{r}0.447 \\
(0.501) \\
\end{array}$ \\
\hline Number of observations & 732 & 628 & 597 & 556 \\
\hline Adjusted R² & 0.339 & 0.392 & 0.156 & 0.373 \\
\hline
\end{tabular}

$* * *=$ significant at $1 \%,{ }^{* *}=$ significant at $5 \%,{ }^{*}=$ significant at 10\%, GDP = gross domestic product,

$\mathrm{LCY}=$ local currency.

Notes:

1. Based on quarterly panel data of 10 emerging Asian economies covering Q1 1996-Q4 2015. Emerging Asia includes the People's Republic of China; Hong Kong, China; India; Indonesia; Republic of Korea; Malaysia; the Philippines; Singapore; Thailand; and Viet Nam.

2. Local currency bonds outstanding as a percentage of total bonds refers to local currency bond outstanding as share of the sum of local currency and foreign currency-denominated bonds.

3. Rule of law refers to World Governance Indicators' rule of law estimate, which captures the perception of agents' confidence in and accordance with the rules of society, including the quality of contract enforcement, property rights, the police, and the courts, as well as the likelihood of crime and violence. The rule of law estimate was converted to a scale of 0 to 100 , with higher value denoting better perception or confidence.

4. Fiscal balance as a percentage of GDP is used. A positive fiscal balance denotes fiscal surplus.

5. Bank lending refers to following - Financial Institution Loans (PRC); Authorized Institutions: Loans and Advances to Customers (Hong Kong, China); Commercial Bank: Domestic Credit (India); Commercial Banks: Loans to Deposit Ratio: Total Credit to Third Party (Indonesia); Loans of Commercial and Specialized Banks (Republic of Korea); Commercial Banks: Loans and Advances (Malaysia); Loans: Universal Commercial Bank (Net of Reverse Repurchase Agreement) (Philippines); Domestic Banking Unit: Loans and Advances (Singapore); Commercial Bank: Loans (Assets) (Thailand); Banking Institutions: Claims on Private Sector (Viet Nam).

6. Sovereign credit rating is based on historical S\&P credit rating on sovereign long-term local currency bonds. S\&P credit rating is transformed such that higher value denotes higher rating.

7. Forex volatility is based on the coefficient of variation of economy's foreign exchange rate against the US dollar.

8. Robust standard errors in parentheses.

Source: Author's calculations based on data from Bank of International Settlements; CEIC Database;

Haver Analytics; various issues of the Asian Development Outlook, ADB; World Governance

Indicators; World Development Indicators, World Bank; and national sources. 
Table 8: Multivariate Tests for Corporate and Long-Term Local Currency Bonds Outstanding

\begin{tabular}{|c|c|c|c|c|}
\hline & \multicolumn{2}{|c|}{$\begin{array}{c}\text { Corporate Bonds } \\
\text { (\% of total local currency bonds) }\end{array}$} & \multicolumn{2}{|c|}{$\begin{array}{c}\text { Long-Term Bonds } \\
\text { (\% of total local currency bonds) }\end{array}$} \\
\hline & $(1)$ & $(2)$ & (3) & (4) \\
\hline Constant & $\begin{array}{l}-46.777^{* * *} \\
(3.204)\end{array}$ & $\begin{array}{c}-63.453^{* * *} \\
(4.15)\end{array}$ & $\begin{array}{l}-49.612^{* * *} \\
(10.524)\end{array}$ & $\begin{array}{l}-37.233^{* * *} \\
(12.649)\end{array}$ \\
\hline Inflation & $\begin{array}{l}-0.247^{* *} \\
(0.113)\end{array}$ & $\begin{array}{l}-0.612^{* * *} \\
(0.151)\end{array}$ & $\begin{array}{l}-0.403^{* * *} \\
(0.121)\end{array}$ & $\begin{array}{l}-0.319^{* * *} \\
(0.123)\end{array}$ \\
\hline Fiscal balance & $\begin{array}{r}0.096 \\
(0.105)\end{array}$ & $\begin{array}{r}0.024 \\
(0.107)\end{array}$ & $\begin{array}{r}0.124 \\
(0.08)\end{array}$ & $\begin{array}{r}0.088 \\
(0.083)\end{array}$ \\
\hline Rule of law & $\begin{array}{l}1.151^{* * *} \\
(0.034)\end{array}$ & $\begin{array}{l}1.052^{* * *} \\
(0.051)\end{array}$ & $\begin{array}{l}1.269^{* * *} \\
(0.2)\end{array}$ & $\begin{array}{l}1.730^{* * *} \\
(0.222)\end{array}$ \\
\hline $\ln (G D P)$ & $\begin{array}{l}2.827^{* * *} \\
(0.424)\end{array}$ & $\begin{array}{r}0.464 \\
(0.511)\end{array}$ & $\begin{array}{r}-0.612 \\
(0.818)\end{array}$ & $\begin{array}{l}6.937^{* * *} \\
(2.487)\end{array}$ \\
\hline In (Bank lending) & & $\begin{array}{l}2.115^{* * *} \\
(0.249)\end{array}$ & & $\begin{array}{l}-7.912^{* * *} \\
(1.952)\end{array}$ \\
\hline Sovereign credit rating & & $\begin{array}{c}1.353^{* * *} \\
(0.282)\end{array}$ & & $\begin{array}{l}0.839^{* *} \\
(0.383)\end{array}$ \\
\hline Forex volatility & & $\begin{array}{l}0.540 \\
(0.51)\end{array}$ & & $\begin{array}{r}-0.140 \\
(0.44)\end{array}$ \\
\hline $\begin{array}{l}\text { Number of observations } \\
\text { Adjusted } \mathrm{R}^{2}\end{array}$ & $\begin{array}{r}708 \\
0.670\end{array}$ & $\begin{array}{r}619 \\
0.708\end{array}$ & $\begin{array}{r}455 \\
0.609\end{array}$ & $\begin{array}{r}455 \\
0.629\end{array}$ \\
\hline
\end{tabular}

${ }^{* * *}=$ significant at $1 \%,{ }^{* *}=$ significant at $5 \%,{ }^{*}=$ significant at $10 \%, \mathrm{GDP}=$ gross domestic product, $\mathrm{LCY}=$ local currency.

Notes:

1. Based on quarterly panel data of 10 emerging Asian economies covering Q1 1996-Q4 2015. Emerging Asia includes the People's Republic of China; Hong Kong, China; India; Indonesia; Republic of Korea; Malaysia; the Philippines; Singapore; Thailand; and Viet Nam.

2. Local currency bonds outstanding as a percentage of total bonds refers to local currency bond outstanding as share of the sum of local currency and foreign currency-denominated bonds.

3. Rule of law refers to World Governance Indicators' rule of law estimate, which captures the perception of agents' confidence in and accordance with the rules of society, including the quality of contract enforcement, property rights, the police, and the courts, as well as the likelihood of crime and violence. The rule of law estimate was converted to a scale of 0 to 100, with higher value denoting better perception or confidence.

4. Fiscal balance as a percentage of GDP is used. A positive fiscal balance denotes fiscal surplus.

5. Bank lending refers to following-Financial Institution Loans (PRC); Authorized Institutions: Loans and Advances to Customers (Hong Kong, China); Commercial Bank: Domestic Credit (India); Commercial Banks: Loans to Deposit Ratio: Total Credit to Third Party (Indonesia); Loans of Commercial and Specialized Banks (Republic of Korea); Commercial Banks: Loans and Advances (Malaysia); Loans: Universal Commercial Bank (Net of Reverse Repurchase Agreement) (Philippines); Domestic Banking Unit: Loans and Advances (Singapore); Commercial Bank: Loans (Assets) (Thailand); Banking Institutions: Claims on Private Sector (Viet Nam).

6. Sovereign credit rating is based on historical S\&P credit rating on sovereign long-term local currency bonds. S\&P credit rating is transformed such that higher value denotes higher rating.

7. Forex volatility is based on the coefficient of variation of economy's foreign exchange rate against the US dollar.

8. Robust standard errors in parentheses.

Source: Author's calculations based on data from Bank of International Settlements; CEIC Database; Haver Analytics; various issues of the Asian Development Outlook, ADB; World Governance Indicators; World

Development Indicators, World Bank; and national sources. 


\section{B. Empirical Results}

The regression results in Table 7 provide evidence that better macroeconomic performance (GDP) contributes to the development of local currency bond markets in terms of sizes and their relative shares of bond markets as a whole. Inflation significantly hinders the overall size of local currency bond markets, but has no significant effect on the share of domestic debt markets that are denominated in local currencies. This may also reflect that low inflation (perhaps effective monetary policy) encourages local currency bond issuance.

The results suggest that in addition to the role of macroeconomic policies, economies with stronger institutions (rule of law) have larger local currency bond markets in terms of share of GDP. This finding is consistent with earlier empirical studies. La Porta, Lopez-de-Silanes, Shleifer, and Vishny $(1997,1998)$ show that better institutions can lead to larger and deeper capital markets and allow firms to make greater use of external finance. Bank lending and sovereign credit rating are also important factors for local currency bond market development. An increase in bank lending suggests an increase in demand for debt financing, and hence positive for local currency bond issuance. Improved sovereign credit rating also positively influences local currency bond market development.

Especially, when bank lending and sovereign credit rating are controlled, the rule of law's effect on the share of local currency bonds in total bonds turns negative, suggesting that it also exerts considerable effect on foreign currency-denominated bonds. While exchange rate volatility shows up significantly positive, it may reflect the positive influence of improvements in macroeconomic management based on increasingly flexible and market-based exchange rate regimes.

Table 8 presents results showing the effects of economic factors on corporate and long-term bond markets separately. The results suggest that the determinants of corporate bond market development are similar to those of local currency bonds; namely, the economies with better macroeconomic performance and stronger rule of law have larger corporate bond markets. High inflation in particular not only discourages the growth in sales of local currency bonds, it also tends to discourage the expansion of issues with longer maturities. Both bank lending and improvements in sovereign credit ratings help encourage corporate bond sales in local currencies.

Surprisingly, exchange rate volatility does not seem to matter so much for the development of the markets for local currency bonds that are either corporate or sold with long-term maturities. However, this finding is consistent with literature pointing to the importance of macroeconomic management and policy-setting conditions in the development of local currency bond markets.

As many emerging market economies adopt more flexible exchange rate regimes, exchange rate volatility alone does not seem to discourage local currency bond market development. The main difference is the effect of bank lending on the percentage of local currency bonds that are sold with long-term maturities. This may reflect the effect of credit constraints on local currency bond market development. If short-term bank loans are easily available, demand for long-term bonds tends to decrease in emerging market economies.

Our results are largely consistent with literature that highlights the importance of macroeconomic performance and institutional strength for local currency bond market development. This literature includes Bae (2012), Burger and Warnock (2006), and La Porta, Lopez-de-Silanes, Shleifer, and Vishny $(1997,1998)$. Countries with better macroeconomic performance and stronger 
institutions tend to develop larger local currency bond markets and also create conditions for the growth in local currency sales of corporate debt and bonds with longer maturities.

The results suggest that there is significant room and leverage for policy makers to encourage local currency bond market development in emerging market economies. As Burger and Warnock (2006) suggest, the results also support the relationship between bond market and banking sector development. That is, bank lending is positively associated with local currency bond market development, except the long-term segment.

\section{THE CHALLENGES AHEAD}

Emerging Asia has come a long way in building local currency bond markets, but significant variations remain in development across the region. While the bond markets of Hong Kong, China; the Republic of Korea; and Singapore are relatively well developed and liquid, markets in the PRC, India, Indonesia, Malaysia and Thailand are still in the early stages of development. Although the PRC and India have the largest local currency bond markets, in terms of market depth and liquidity, they fall short of potential.

Bond issuance data also shows variations in sectoral diversity, issuing volume, and consistency. Bond markets in the PRC and India also remain relatively less open to foreign investors despite being much larger than those in Indonesia, the Republic of Korea, Malaysia, and Thailand.

Rapid growth in bond markets has helped diversify the sources of corporate financing in the region, but more needs to be done to enable the private sector to obtain funding from a broader range of sources without increasing vulnerability to shocks. The region's demographic changes and substantial needs for infrastructure and urban development also suggest long-term funding needs will only increase. Asia's investment needs for infrastructure are indeed substantial-as much as $\$ 8$ trillion in the 10 years to 2020 (ADB and ADBI 2009). Fiscal spending alone would not be sufficient to address the funding gap. Robust local capital markets are essential to diversify the sources of funding necessary to support long-term investments and sustain emerging Asia's high growth rates.

However, structural impediments to growth in corporate bond markets remain. The rapid growth of emerging Asia's corporate bond markets has been an outcome of regional initiatives to build financial resilience and reduce currency mismatches in the postcrisis period. The first step was to establish well-functioning government bond markets. In doing so, many economies encouraged sales of locally rated or unrated debt to encourage the use of bond markets. For example, the CGIF provides guarantees for debt sold by firms that would otherwise be constrained in securing long-term funding through local bond markets. Another example is Thailand's Securities and Exchange Commission, which began to allow the sale of unrated bonds to accredited investors.

Many local currency bond markets have also seen substantial progress in market infrastructure, including much-improved settlement and clearing systems. Local agencies for regulatory, supervisory, and enforcement functions covering issuers and investors play an important role. The regulatory framework should cover (i) the issuance procedures to reduce cost and simplify the issuance and approval process, (ii) the licensing structure to better define the role of intermediaries and their functions, (iii) an investment framework for nonbank institutional investors to invest in corporate bonds, (iv) the establishment of over-the-counter trading, custody and settlement mechanisms, and price reporting for corporate bonds, and ( $v$ ) credit rating requirements. 
To manage the transition to a more resilient bond market, key areas of reform focus are improving market efficiency, broadening the investor base, deepening secondary markets, and integrating regional markets. These reform efforts will also help the region to more efficiently absorb large capital flows and channel these into long-term productive investments.

\section{A. Size and Liquidity in Secondary Markets}

Despite fast growth in primary issuance in many emerging Asian markets, secondary market trading volumes and liquidity remain limited. A deep and liquid secondary market can reduce liquidity risks and allow investors to exit from long-term bonds before their maturity, contributing to greater demand for such issues. However, various measures of market liquidity indicate there is room for improvement in the region's corporate bond markets. Bid-ask spreads for corporate bonds are typically wider than those for sovereign bonds. Corporate bond turnover ratios, which measure the value of bonds traded in secondary markets relative to the size of bonds outstanding, are also low. New issues are often traded only for short periods. Lack of risk management products hampers secondary market trading and liquidity.

A positive impact on secondary market liquidity can come from the introduction of bond buybacks and exchanges, and through building active cash management capacity along with broadening the range of more sophisticated market instruments and segments. Legal infrastructure also needs to be improved to develop markets for repurchase (repo) agreements and derivative contracts.

Key reforms in these areas can typically include (i) enhancing primary and secondary market architecture to provide the appropriate level of market transparency; (ii) promoting market-making activities to increase liquidity (including the primary dealers system, where appropriate); (iii) introducing prudential norms and risk management practices of market participants; (iv) increasing the size of benchmark bonds and extending the yield curve; ( $v$ ) moving toward a more market-based implementation of monetary policy and more emphasis on the interbank repo market; and (vi) fostering institutional investment and promoting foreign participation.

\section{B. Strengthening the Supportive Market Infrastructure}

The region also needs to improve supporting market infrastructure such as standardized credit rating systems, risk management products, and a functioning trading and settlement system. In tandem, the strengthening of legal and regulatory frameworks could encompass various auxiliary markets such as interest futures, and seek to bring accounting and taxation in line with international best practices. Establishment of a reliable benchmark yield curve also helps enhance market efficiency and transparency in the pricing of corporate bonds.

It is also important to broaden the investor base and develop appropriate risk management instruments along with the extension of the yield curve. In emerging Asian markets, where banks are the predominant investors, efforts to extend the yield curve could simply transfer interest rate and liquidity risks from the government to the banking sector.

While reform efforts should continue to refine and upgrade supporting market infrastructure, and also bring the legal and institutional framework into line with those of more advanced markets, more targeted efforts would be needed to address cross-border barriers to regional integration. The launch of a pilot platform for cross-border clearing and settlement of debt securities in Hong Kong, China and Malaysia is a good example, aimed at strengthening post-trading infrastructure and promoting the standardization and dissemination of corporate announcements across emerging Asian markets. 


\section{Broadening the Investor Base}

Banks are often the largest group of investors in emerging Asia's corporate bond markets, but tighter capital requirements facing these banks may contribute to lack of liquidity in secondary markets. Lack of investor diversity can also lead to high volatility and expose the market to sector-specific risks. In the PRC, most outstanding corporate bonds are held by state-owned commercial banks, which in turn are heavily exposed to state-owned enterprises.

Encouraging institutional investors, such as pension funds and insurance companies, can help contribute to the development of long-term bond markets. Although domestic institutional investors hold much less assets in most emerging Asian markets than in advanced markets, they tend to play an increasingly important role in corporate bond markets. In the Republic of Korea, the combined holdings of pension funds and insurance companies account for nearly a half of the market.

Foreign investors' investment horizons and preferences may differ from domestic investors, which can result in improved demand structure and secondary market liquidity. Foreign investors could be allowed to operate in local markets with fewer restrictions and foreign financial institutions could assume new roles such as intermediaries or asset managers. However, allowing foreign investors to enter local bond markets should be handled with care, as foreign participation in small, illiquid markets could undermine financial stability through sudden capital outflows creating volatility in interest rates and exchange rates.

\section{Regional Integration}

Emerging Asian bond markets are growing at a healthy clip. It is important that this expansion is accompanied by strengthening market infrastructure within the context of regional cooperation. Integration has lagged behind the interconnectedness seen in other markets, for example in equities. Levinger and Li (2014) find that Asian local currency bond markets are not effectively integrated, although the degree of integration varies across the region. Some markets (Malaysia; Taipei,China; and Thailand) are relatively better integrated than others (the PRC, Indonesia, and the Philippines).

Regional initiatives and policies to date have focused on promoting regional integration of emerging Asian bond markets. The latest example is the launch of a bond pricing portal among five banks across ASEAN economies in 2013, which is meant to pave the way for an electronic trading platform, mirroring a similar project to integrate trading of equities. Five banks from Indonesia, Malaysia, the Philippines, Singapore, and Thailand quote the prices for local bonds and distribute them through Bloomberg trading terminals. The initiative is part of the efforts to create a more integrated capital market in ASEAN economies by facilitating access to price information about cross-border bonds. A road map for capital market integration has been agreed as part of the ASEAN Economic Community. This should pave the way for greater and more resilient use of the corporate bond market.

While deeper market integration brings many benefits in theory, such as more efficient resource allocation and better enforcement of market disciplines, it can increase the risk of financial contagion and spillovers. It is therefore critical to enable regional regulatory authorities to develop and implement appropriate regulatory frameworks to facilitate market development and integration, while safeguarding financial stability during a transition where increased competition and financial innovation could lead to increased risk-taking and undermine financial stability. 


\section{REFERENCES}

Asian Development Bank. 2008. ASEAN+3 New ABMI Roadmap. Manila.

2012. ASEAN+3 Bond Market Guide. Manila.

2015. Implementation of the ASEAN+3 Multi-Currency Bond Issuance Framework: ASEAN+3 Bond Market Forum Sub-Forum 1 Phase 3 Report. Manila.

Asian Development Bank and Asian Development Bank Institute. 2009. Infrastructure for a Seamless Asia. Tokyo: ADBI.

Bae, Kee-Hong. 2012. "Determinants of Local Currency Bonds and Foreign Holdings: Implications for Bond Market Development in the People's Republic of China." ADB Working Paper Series on Regional Economic Integration No. 97.

Bank for International Settlements. 1999. Market Liquidity: Research Findings and Selected Policy Implications. http://www.bis.org/publ/cgfs11.htm

Burger, John D., and Francis E. Warnock. 2006. “Local Currency Bond Markets.” IMF Staff Papers Vol. 53, Special Issue.

La Porta, Rafael, Florencio Lopez-de-Silanes, Andrei Shleifer, and Robert W. Vishny. 1997. "Legal Determinants of External Finance." The Journal of Finance 52 (3): 1131-50.

_. 1998. "Law and Finance." The Journal of Political Economy 106 (2): 1113-55.

Levinger, Hannah, and Chen Li. 2014. "What's behind recent trends in Asian corporate bond markets?" Current Issues: Emerging Markets, January 31.

Tendulkar, Rohini, and Gigi Hancock. 2014. "Corporate Bond Markets: A Global Perspective." Staff Working Paper of the IOSCO Research Department. 


\section{Developing Local Currency Bond Markets in Asia}

This paper reviews the advances made in developing local currency bond markets in emerging Asia. While progress in Asian local currency markets has been remarkable, hurdles to developing the market for local currency corporate bonds remain large in the shape of market infrastructure and institutions, inconsistent policies and regulations, and-more broadly-in poor corporate governance; and cross-country variances are significant. The paper empirically investigates economic factors associated with expanding local currency bond markets and highlights the importance of macroeconomic performance and institutional strength as key areas for further reforms.

\section{About the Asian Development Bank}

ADB's vision is an Asia and Pacific region free of poverty. Its mission is to help its developing member countries reduce poverty and improve the quality of life of their people. Despite the region's many successes, it remains home to half of the world's extreme poor. $A D B$ is committed to reducing poverty through inclusive economic growth, environmentally sustainable growth, and regional integration.

Based in Manila, ADB is owned by 67 members, including 48 from the region. Its main instruments for helping its developing member countries are policy dialogue, loans, equity investments, guarantees, grants, and technical assistance. 